DOI 10.18551/rjoas.2021-12.15

\title{
ANALYSIS OF ECONOMIC MODEL OF TERASAK FISHERMAN'S HOUSEHOLD AT MADURA STRAIT
}

\author{
Primyastanto M.*, Supriyadi Supriyadi, Sari M., Intyas C.A., Abdillah K.I. \\ Faculty of Fisheries and Marine Science, University of Brawijaya, Malang, Indonesia \\ *E-mail: mimitp@ub.ac.id
}

\begin{abstract}
In dry season, the income level of fishermen is very minimal and they often do not get any catches at all. In periods of low income, fishermen's wives and children usually have to fight hard to earn money by doing all the work that brings income. The purpose of this research is to analyze Household Economic Model of Fishermen Terasak at Madura Strait. Samples were taken comprised of two groups, namely fishhook skipper and gillnet fishermen. Several samples were taken from each group. Respondents were determined by "purposive sampling" method. Researchers took 31 families of small-scale terasak fisherman at Madura Strait. Data analysis used qualitative and quantitative descriptive (regression analysis). Whereas qualitative descriptive analysis was used to analyze and compare factors that are affecting fishermen family economy. Research results showed Household Economic Model of Madura Strait Terasak Fishermen that the production value or fishing income of Madura Strait fishermen is strongly influenced by Production Assets, Fuel, Working time and Education Level. The working time fishermen's family's level is influenced by production assets, the number of fisherman members and non-fisheries working time. The level of nonfisheries income is strongly influenced by non-fishing business assets, non-fisheres working time, number of family members. The level of expenditure of Madura Strait fishermen is influenced by fishing income, non-fisheries income, number of family members and education of fishermen's wives. Spending levels for Madura Strait fishermen were affected by fishing income, non-fishing income, family size, and the fisherman's wife's education. Variables in fishing working time and education are not significant relate to fishing production. The non-fisheries working time variable is not significant to non-fisheries income. Variables in the production assets, number of fishermen's families, and non-fisheries working time are not significant to the fishing working time The variables of total household income, number of family members, and education of fishermen's wives are not significant to the total of staple consumption.
\end{abstract}

\section{KEY WORDS}

Gillnet, fishermen terasak, household economics, Madura Strait.

Indonesia is known as maritime country that has water (sea) three times larger than the land so it has many potential in fisheries aspects. With such potential, marine development in Indonesia today has purpose to improve their resources as well as increase the functions of the national marine area, including the ZEE in a harmony and appropriate by concern in carrying capacity of the sea and its sustainability to increase people's welfare and develop business and field work opportunities [2]. Indonesia has the longest coast in the world with more than $81,000 \mathrm{~km}$ of the coastline. It also has 67,439 villages that approximately 9,261 villages are categorized as coastal villages and most of their citizens are poor. Coastal villages are potential pockets of poverty, especially in structural aspect. The difficulty of overcoming poverty has made citizen in this area have to bear the burden of life which cannot be ascertained when the period ends [3].

The phenomena of poverty then overfishing are complex and multidimensional. How they are lived is often used as measuring tool for poverty but is only one part in chain of factors that cause the poverty syndrome. From a political-economic point of view, poverty is understood as a product of economic forces, the relation of production, and authority which in their entirety result in the process of poverty. These pressures faced by fisherman 
household that have been rooted in complex interrelated factors. Natural factors are the fluctuations in fishing season and the natural structure of economic resources whereas nonnatural factors are the limited asset of fishing technology, weak marketing networks and the negative impact of policies on fisheries aspect since the last quarter century [4].

Characteristics of fishing communities are different from those of farming communities due to differences in the resources they have. Farming (agrarian) communities face controlled resources, namely land that the place to produce commodities with predictable results, it is possible to have a permanent production location, so the business can be stable, and the risk factor is relatively small. In the dry season, the income level of fishermen is very minimal, and they often do not get any fish at all. This low catch season lasts about 8 months and the accumulated savings obtained during the fishing season will not be sufficient to overcome the difficulties of daily living needs of fishermen's households. In periods of low income, fishermen's wives and children usually have to fight hard to earn a living by doing all the work that brings income [5].

Likewise, when not at sea, fishermen can work anything on land to earn income so the live of their household can be guaranteed. However, how far these job opportunities can be obtained by fisherman's household is influenced by the characteristics of the local village economic resource structure. [6]. In coastal villages whose economic resource structures depend entirely on marine fishery production, job opportunities are very limited and other business sectors that usually rely on the raw materials procurement from marine products will stop operating so that employment opportunities cannot continue continuously. According to [7] fishing business is an exploitative business, where this business includes a risky business not getting results because this business depends entirely on nature.

A primary issue in this study; how is the household economic and economic model of terasak fishermen at Madura Strait.

\section{MATERIALS AND METHODS OF RESEARCH}

The method using qualitative descriptive on natural situation and collecting qualitative data. Qualitative methods are based on phenomological philosophy that prioritizes appreciation and seeks understanding and interpreting the human behavior interaction in certain situations [8]. This qualitative descriptive analysis is used to see and find out the characteristics in this study which become cases or problems, namely poverty alleviation and food security experienced by small-scale fishermen in Lekok Pasuruan District. The unit of study in the case study can be individuals, families, groups, and certain communities who are small-scale fishing and gillnet skipper fishermen.

While the survey approach is research that takes sample from population and uses questionnaire for the primary data collection tools. It is also explained that one of the main advantages of this study is that it allows generalizations to a large population. Survey method can be used to predict the certain condition of social phenomena and evaluate research results [9].

This research used qualitative data and quantitative data. The use of qualitative data is used for providing detail explanations about the existing phenomena. The techniques of data collection were carried out by documentation, interviews and questionnaires [10].

The data collected in this research need two kinds of data which includes primary and secondary data. Primary Data is based on primary information sources and provides information and data that directly get from self-collection [11].

The primary data were sourced from related parties in the research area. Primary data is determined by structured questionnaire technique that distributed to small fishermen, especially fishing tools and gillnets [12]. Secondary data is data that has been collected by outside researcher and published in general [13]. This data comes from various literatures such as textbooks, journals of research, research reports, data from relevant agencies, etc. Secondary data also can be said as processed data.

The sample taken is part of the population which is the real object in a study [14]. while the population or universe is the total number of units of analysis whose characteristics will 
be estimated [15]. In this study, the population was small scale fishermen, especially terasak fisherman skipper and gillnets who do fishing activities.

In accordance with the problems, objectives, and research focus. Researchers need to interview several informants who are considered to really know or are directly involved in small fishermen's household business activities in Lekok, knowing the problems of fishermen in Lekok. In this case, the samples taken consisted of two groups of small fishermen, namely small-scale gillnet fishermen. From each group, several samples were taken. In this case the respondents who are taken are determined by the "purposive sampling" method, namely sampling where in taking the intended elements in the sample it is done intentionally with a record sample taken representative [16].

In this study, the researchers took 31 families of small-scale gillnets grinded by purposive sampling with the following sampling criteria: 1) The fishing technology used is simple with a small boat size of less than 30 Grosston (GT) 2) use less than 12 PK mesin engine, 3). The amount of business capital is limited, 4) The number of members of the organization is generally based on relatives, close neighbors, and/or close friends. 5) Its orientation on economics is relate to basic daily needs and 5) Types of food used to meet the needs of fishermen [17].

The data analysis techniques used descriptive analysis on qualitative and quantitative with regression analysis. Quantitative descriptive analysis was used for analyzing the environmental conditions of the research location, the work behavior of the fishermen's families, and the expenditure of fishermen's production costs. While the descriptive qualitative analysis is used for analyzing and comparing the factors that effect to the economy owned by the fishermen's $h$, which include the variables of family income, production income, family consumption and the outpouring of fisherman's working time. [18].

Analysis of regression is generally used for analyzing the relationship between 2 or more variables. So, it is known which variables are influenced by other variables and which ones are affected. The variable that get impact is called the dependent variable, while the variable that give effect is called independent variable [19].

Multiple regression analysis is dependency technique. So, for using it, we should be able to determine the variable into dependent variables or independent variables. Regression analysis is statistical tool that used when the dependent and independent variables are in the form of a matrix. However, in some certain circumstances, non-metric data variables (dummy variables, ordinal data or nominal data) can be used. [20].

Multiple linear regression analysis was used to analyze the relation between the factors that influence food security in fisherman households, which includes the factors that exist in the variables of production revenue, income, consumption expenditure, and working time.

In this study there are several dependent variables, namely the dependent variable of Fishing Production Revenue (FPR), the dependent variable of non-fishing income (NFI), the dependent variable of fishing working time (FWT), and the dependent variable of Total Staple Consumption (TSC).

Regression model used to see the relation between one dependent variable with several independent variables [21]. It called multiple regression models. The multiple linear regression model used in this data analysis.

a. Fishing Production Revenue (FPR):

$$
\begin{gathered}
Y=a+b_{1} x_{1}+b_{2} x_{2}+b_{3} x_{3}+\ldots \ldots+b_{k} x_{k}+e \\
F P R=a+b_{1}+b_{2} P A+b_{3} F F O+b_{4} F W T+b_{5} F E+e^{u}
\end{gathered}
$$

Where:

FPR: Fishing Production Revenue (kg/year);

PA: Production Aset (IDR);

FFO: Fuel Amount for Fishing Operations (Ltr/year);

FWT: Fishing Working Time (HOK/year);

FE: Fishermen Education (year). 
b. Non-Fisheries Income (NFI):

$$
\begin{gathered}
Y=a+b_{1} x_{1}+b_{2} x_{2}+b_{3} x_{3}+\ldots \ldots+b_{k} x_{k}+e \\
N F I=a+b_{1} N W F+b_{2} F F M+b_{3} N B A+e^{u}
\end{gathered}
$$

Where:

NFI: Non Fisheries Income (IDR /year);

NWT: Non FisheriesWorking Time (HOK/year);

FFM: Fishermen Families Members (Person);

NBA: Non Fishing Business Asset (IDR).

c. Fishing Working Time (FWT):

$$
\begin{aligned}
& Y=a+b_{1} x_{1}+b_{2} x_{2}+b_{3} x_{3}+\ldots \ldots+b_{k} x_{k}+e \\
& W F T=a+b_{1} P A+b_{2} F F M+b_{3} N W F+e^{u}
\end{aligned}
$$

Where:

WFT: Fishing Working Time (HOK/year);

PA: Production Asset (IDR);

FFM: Fishermen Families Members (Person);

NWT: Non Fisheries Working Time (HOK/year).

d. Total Staple Consumption Fishermen (TSC):

$$
\begin{aligned}
Y & =a+b_{1} x_{1}+b_{2} x_{2}+b_{3} x_{3}+\ldots \ldots+b_{k} x_{k}+e \\
T S C & =a+b_{1} F I+b_{2} N F I+b_{3} F F M+b_{4} F W E+e^{u}
\end{aligned}
$$

Where:

TSC: Total Staple Consumption Fishermen (IDR/year);

FI: Fisheries Income (IDR/year);

NFI: Non Fisheries Income (IDR/year);

FFM: Fishermen Family Members (Person);

FWE: Fisherman's wife education (Years).

\section{RESULTS OF STUDY}

There are several variables that are hypothise affecting Fishing Production Revenue (FPR), namely production assets (PA), Fuel Amount for Fishing Operations (AFO), Fishing Working Time (FWT), Fishermen Education (FE). The results of the calculation to determine the relationship of these independent variables with the dependent variable fishing production revenue (FPR) as follows:

Table 1 - Regression Results of Factors Affecting Fishermen Terasak Household: Fishing Production Revenue (FPR)

\begin{tabular}{llll}
\hline Variables & Coef. & $\mathrm{t}$ & Sig. \\
\hline Constant & $-48.785 \mathrm{E} 7$ & -1.83 & $0.098^{\star}$ \\
PA & 5.859 & 2.059 & $0.049^{\star *}$ \\
AFO & 0.041 & 3.285 & $0.002^{* \star *}$ \\
FWT & -0.395 & -1.049 & $0.301 \mathrm{NS}$ \\
FE & 1.497 & 0.693 & $0.450 \mathrm{NS}$ \\
Adjusted $\mathrm{R}^{2}$ & 0.653 & & \\
F & 8.785 & & $0.000^{\star * *}$ \\
$\mathrm{~N}$ & 31 & & \\
\hline
\end{tabular}

From the table 1, it can be seen the regression equation is:

$$
\left.F P R=-48.785 \times 10^{7}+5.859 \mathrm{PA}+0.041 \mathrm{AFO}-0.039\right) \mathrm{FWT}+1.497 \mathrm{FE}+\mathrm{e}^{\mathrm{u}}
$$


Constanta of $-48.785 .049 .892 \times 10^{7}$ states that if all variables not affected, fisherman will be a loss for IDR - 48,785,000.

The Regression coefficient of 5.859 PA states that for each additional 1 unit of production assets, it will increase fishing production revenues by IDR 5.859 .

The Regression coefficient of 0.041 AFO states that each addition of 1 liter of fuel oil will increase the acceptance of fishing production by IDR 0.041 fish production.

The Regression coefficient of -0.395 states that each additional 1 HOK of fishing work will reduce fishing revenues by IDR 0.039 [22]. this is because a person's maximum work in 1 day is 8 hours, so if an additional number of working hours, it will reduce the maximum revenue and also the condition of fisheries resources are overfishing so that working time of fishing is not optimal.

The Regression coefficient of 1.497 FE states each addition of 1 unit of production assets will increase fishing production revenues by IDR 1.47. So, improving technology and fishing gear will increase the productivity of fishermen [23].

3.2. Regression Analysis of Non-Fisheries Income (NFI)

The factors that affect non-fisheries income (NFI) are several variables, namely Production Asset (PA), Fishermen Families Members (FFM) and Non-Fisheries Working Time (NWT). The results of calculations to determine the relation of these independent variables with the dependent variable of non-fisheries income as follows:

Table 2 - Regression Results of Factors Affecting Fishermen Terasak Household: Non Fisheries Income (NFI)

\begin{tabular}{llll}
\hline Variables & Coef. & $\mathrm{t}$ & Sig. \\
\hline Constant & -0.072 & -0.033 & 0.978 \\
NWT & 0.039 & 2.751 & $0.011^{* \star *}$ \\
FFM & 0.021 & 0.320 & $0.765 \mathrm{NS}$ \\
NBA & 0.013 & 2.767 & $0.011^{\star \star \star}$ \\
Adjusted $\mathrm{R}^{2}$ & 0.519 & & \\
F & 6.795 & & $0.021^{* \star}$ \\
$\mathrm{N}$ & 31 & & \\
\hline
\end{tabular}

From the table 2, it can be seen the regression equation is:

$$
\mathrm{NFI}=-0.072+0.039 \mathrm{NWT}+0.021 \mathrm{FFM}+0.013 \mathrm{NBA}+\mathrm{e}^{\mathrm{u}}
$$

Constanta of -0.072 stated that if that if all variables not affected, fisherman will lose non-fishing income for IDR 0,072.

The regression coefficient of 0.039 NWT states that each additional 1 unit of nonfisheries business assets will increase non-fisheries income by IDR 0.039 .

The regression coefficient of $0.021 \mathrm{FFM}$ states that each additional $1 \mathrm{HOK}$ non-fishing working time, it will increase non-fisheries income by IDR 0.021 .

The regression coefficient of 0.013 states that for each additional number of family members 1 person, it will increase non-fisheries income by IDR 0.013 [24].

The factors that are hypothise to affect non-fisheries income (NFI) are several variables, namely Production Asset (PA), Fishermen Families Members (FFM), NonFisheries Working Time (NWT). Calculations results to determine relation of independent variables with dependent variable of non-fishery income as follows.

Table 3 - Regression Results of Factors Affecting Fishermen Terasak Household: Fishing Working Time (FWT)

\begin{tabular}{llll}
\hline Variables & Coef. & $\mathrm{t}$ & Sig. \\
\hline Constant & 368.75 & 3.201 & $0.004^{* \star *}$ \\
PA & -1.505 & -1.195 & $0.244 \mathrm{NS}$ \\
FFM & -16.769 & -0.428 & $0.671 \mathrm{NS}$ \\
NWT & -0.190 & -0.545 & $0.592 \mathrm{NS}$ \\
Adjusted $\mathrm{R}^{2}$ & 0.075 & & \\
F & 0.697 & & $0.555 \mathrm{NS}$ \\
N & 31 & & \\
\hline
\end{tabular}


From the table 3, it can be seen the regression equation is:

$$
F W T=368.75-1.505 \text { PA -16.769 FFM -0.190 NWT }+e^{u}
$$

Constanta of 368.75 states that if all variables not affected, then fishermen have fishing working time of 3687.75 HOK.

The regression coefficient -1.505 PA states that each additional number of production assets will reduce the fishing working time by $1.505 \mathrm{HOK}$. This negative relation because the addition of production assets will increase the productivity of fishermen from the technological improvement so that fishermen work less physically with using better technology. Unpredictable weather/season and overfishing waters indication are the other factors. This requires the development of local wisdom and to find fishery resources which is not optimal yet [25].

The regression coefficient $-16,769$ FFM states that every increase in the number of male fishermen's labor force will reduce the outpouring of fisherman's working time at sea by $16,769 \mathrm{HOK}$. It was obtained negative results indicating that the waters in Lekok were over fishing, this was related to the negative results obtained from FFM and also the small number of male fishing families. Because they work as carpenters, workshops and construction workers [26].

The regression coefficient -0.190 NWT states that each additional non-fisheries working time will reduce fisheries working time by $-0,190 \mathrm{HOK}$. this is due to the amount of working time switching from fisheries to non-fisheries sector but the amount of non-fisheries working time is small so the main income is from fishing, so that non fisheries working time usually done by other family member expecially the fishermen's wives who do fish processing according to local wisdom that exists in the fishing community [27].

The factors that are hypothise affected the Total Staple Consumption Fishermen (TSC) was Non Fisheries Income (NFI), Fishermen Family Members (FFM), and Fisherman's wife education (FWE). Calculations results to determine relation of independent variables with dependent variable of Total staple consumption Fishermen (TSC), as follows:

Table 4 - Regression Results of Factors Affecting Fishermen Terasak Household: Total Staple Consumption Fishermen (TSC)

\begin{tabular}{llll}
\hline Variables & Coef. & T & Sig. \\
\hline Constant & 14.143 & 3.201 & $0.001^{* \star}$ \\
FI & -0.014 & 3.995 & $0.757 \mathrm{NS}$ \\
NFI & -0.205 & -3.118 & $0.552 \mathrm{NS}$ \\
FFM & -0.497 & -8.395 & $0.409 \mathrm{NS}$ \\
FWE & 0.197 & 0.496 & $0.594 \mathrm{NS}$ \\
Adjusted $\mathrm{R}^{2}$ & 0.055 & & \\
F & 0.349 & & $0.838 \mathrm{NS}$ \\
$\mathrm{N}$ & 31 & & \\
\hline
\end{tabular}

From the table 4, it can be seen the regression equation is:

$$
\text { TSC }=14.143-0.014 \mathrm{FI}-0.205 \mathrm{NFI}-0.497 \mathrm{FFM}+0.197 \mathrm{FWE}+\mathrm{e}^{\mathrm{u}}
$$

Constanta of 14,143 states that if all variables not affected, fishermen have a total Staple consumption of IDR 13,821.

The regression coefficient $-0.014 \mathrm{FI}$ states that each additional fisheries income will reduce total staple consumption by IDR 0.014 . This is because to increase business investment in order to increase alternative income, as well as the influence of fisheries income where marine resources are already over fishing.

The regression coefficient $-0.205 \mathrm{NFI}$ states that each additional non-fisheries income will reduce the total consumption of fishermen by IDR 0.205 . The negative relation with nonfisheries income because very few fishermen work in non-fisheries sector. This means that fishermen still depend on their income from fishing. 
The regression coefficient -0.497 states that each additional number of fishermen's family members will reduce the total family staple consumption by IDR 0.497 . This is linear with the increase in the number of fisherman's family members, the total expenditure on food consumption and non-food consumption of basic consumption will also increase. So that the quantity and quality will decrease with a relatively constant amount of income but the amount of consumption increases. This is appropriate with the theory of meeting basic needs on other consumption (28).

The regression coefficient of 0.197 states that every increase in the level of fishermen's education will increase the total level of basic consumption by IDR 0.197 . its because the higher fishermen's human resources, the higher the education budget will be spned on the total consumption of Madura Strait fishermen's families (29).

\section{CONCLUSION}

This research was conducted on fishermen of terasak gillnet. It can be concluded that the Fisherman's Household Economic Model in the Madura Strait:

- The production value or fishing income of Madura Strait fishermen is strongly influenced by Production Assets, Fuel, Working time and Education Level;

- The working time fishermen's families level is influenced by production assets, the number of fisherman members and non-fisheries working time;

- The level of non-fisheries income is strongly influenced by non-fishing business assets, non-fisheres working time, number of family members;

- The level of expenditure of Madura Strait fishermen is influenced by fishing income, non-fisheries income, number of family members and education of fishermen's wives.

From the Study of Fishermen's Household Economics, it is suggested:

- Economic Model of Terasak Fisherman should fulfill basic needs as food, clothing, shelter, health and education;

- Government should provide enough infrastructure and production facilities (Ships asset value and fishing tool) so small-scale fisherman could get cheap price with good quality;

- Need improvement institutional role of Madura Strait fisherman communities as collective action goals;

- Need improving of promotion productive economic activities in areas based on local characteristic resources; make a great market but also considering for sustainability of fisheries resources capacity and local communities and using appropriate technology for catch the fish.

\section{ACKNOWLEDGEMENTS}

The authors are grateful to Candra Adi Intyas, Mariyana Sari, Supriyadi, and anonymous referee for constructive comments. The authors would like to thank all those who have contributed, either directly or indirectly, in writing this article until finished. And individuals who provided help during the research (e.g., providing language help, writing assistance or proofreading the article, etc).

\section{REFERENCES}

1. Departemen Agama RI 2015 Al-Qur'an Terjemahan (Bandung: CV. Darus Sunnah).

2. Primyastanto M 2011 Kebijakan Perikanan Lebih Tangkap (Malang: Program Pascasarjana Universitas Brawijaya).

3. Kusnadi 2000 Nelayan Strategi Adaptasi dan Jaringan Sosial (Bandung: Humaniora Utama Press).

4. Kusnadi 2002 Konflik Sosial Nelayan, Kemiskinan dan Perebutan Sumber Daya Perikanan (Yogyakarta: LkiS). 
5. Stevanus S 2005 Pengelolaan Sumberdaya Pesisir dan Laut Melalui Pemberdayaan Kearifan Lokal di Kabupaten Lembata, Propinsi Nusa Tenggara Timur (Semarang: Thesis PPS-UNDIP).

6. Primyastanto M 2012 Policy Pengelolaan SDI (Sumberdaya Ikan) pada Perikanan Over Fishing (Lebih Tangkap) (Malang: Universitas Brawijaya Press).

7. Reardon $\mathrm{T}$, et al 2006 Husehold income diversification in to rural nonfarm activities In Steven Haggblade, Peter Hazell, and Thomas Reardon (Eds), Transforming the rural nonfarm economy (Baltimore: John Hopkins University Press).

8. Usman H dan Akbar P S 2006 Metode Penelitian Sosial (Jakarta: PT. Bumi Aksara).

9. Arikunto, S 2006 Prosedur Penelitian Suatu Pendekatan Praktek ed V (Yogyakarta: Rineka Cipta).

10. Khoiriyah A 2005 Alternatif Permodalan dalam Upaya Pemberdayaan dan Penanggulangan Kemiskinan Nelayan Tradisional (Studi tentang Kondisi Permodalan Nelayan Tradisional di Desa Weru, Kecamatan Paciran, Kabupaten Lamongan, Jawa Timur) (Malang: Skripsi Fakultas Perikanan Universitas Brawijaya).

11. Sugiyono 2015 Metode Penelitian Bisnis (Pendekatan Kuantitatif, Kualitatif dan R \& D) (Bandung: Alfabeta).

12. Lina A W dan Primyastanto M 2018 Ekonomi Produksi Perikanan dan Kelautan Modern (Teori dan Aplikasinya) (Malang: UB Press).

13. Nazir M 2009 Metode Penelitian (Jakarta: PT Ghalia Indonesia).

14. Koentjoroningrat 1991 Metode-metode Penelitian Masyarakat (Jakarta: Gramedia Pustaka Utama).

15. Singarimbun M dan Effendi S 1987 Metode Penelitian Survei (Jakarta: Penerbit LP3ES).

16. Marzuki 2005 Metodologi Riset (Yogyakarta: Ekonisia).

17. Suharjo B 2008 Analisis Regresi Terapan dengan SPSS (Yogyakarta: Graha IImu).

18. Muhammad S 2002 Kajian Ekonomi Rumah Tangga Nelayan di Jawa Timur: Analisis Simulasi Kebijakan, Pemanfaatan Sumberdaya Perikanan (Bogor: Disertasi PPS IPB).

19. Narbuko C dan Achmadi A 2008 Metodologi Penelitian (Jakarta: PT Bumi Aksara).

20. Sulaiman 2010 Model Alternatif Pengelolaan Perikanan Berbasis Hukum Adat Laot di Kabupaten Aceh Jaya, Menuju Keberlanjutan Lingkungan yang Berorientasi Kesejahteraan Masyarakat (Semarang: Tesis Program Pascasarjana UNDIP).

21. Nachrowi D N dan Usman H 2002 Penggunaan Teknik Ekonometri: Pendekatan Populer dan Praktis Dilengkapi Tekhnik Analisis dan Pengolahan Data dengan Menggunakan Paket Program SPSS (Jakarta: Radja Grafindo Persada).

22. Yamin S, et al 2011 Regresi dan Korelasi dalam Genggaman Anda (Aplikasi dengan Software SPSS, Eviews, MINITAB, dan STATGRAPHICS) (Jakarta: Salemba Empat).

23. Primyastant M 2011 Pengelolaan Sumberdaya Ikan (SDI) Berkelanjutan: Pendekatan Bioekonomi (Malang: Program Pascasarjana Universitas Brawijaya).

24. Primyastanto M 2016 Effect the usage of axle and second ship helper on fish capture of purse seine fishermen in banyuwangi district, indonesia J. AJMBES 18(2) 297-303.

25. Primyastanto M, Soemarno, Efani A dan Muhammad S 2013 Fisheries resources management by empowering the local wisdom in madura straits. J. IISTE 3(6) 13-21.

26. Primyastanto M 2016 Feasibility study of fish capture with payang tool before using electronic onjhem fads in madura strait indonesia. J. IJABER 14(9) 6615-28.

27. Primyastanto M 2011 Kearifan Lokal Untuk Pengelolaan Sumberdaya Ikan Lebih Tangkap (Malang: Program Pascasarjana Universitas Brawijaya).

28. Primyastanto M 2015 Economic analysis of pandega fishermen household at madura strait to keep food security. J. IJOO 9(2) 97-104.

29. Primyastanto M 2017 The Cobb-Douglass production function model on trawling fishermen in Probolinggo, East Java. J. IJER 14(10) 233-45. 